\title{
FOOD-GIFTING IN GDAŃSK: BETWEEN FOOD NOT BOMBS AND THE FOOD BANK
}

\author{
ALEKSANDRA GRACJASZ ${ }^{\mathrm{a}}$, CRISTINA GRASSENI ${ }^{\mathrm{b}}$ \\ ${ }^{a}$ LEIDEN UNIVERSITY \\ ${ }^{\mathrm{b}}$ LEIDEN UNIVERSITY
}

\begin{abstract}
The Food Citizens? project compares cases of collective food procurement in three countries of the European Union (Poland, Italy and the Netherlands), specifically in three post-industrial cities of comparable size and population, namely Gdansk, Turin and Rotterdam. The project explores how networks of social actors organize themselves at comparable levels of intervention (foraging, namely gathering or producing food themselves; short food chains, namely engaging directly with producers; governance, namely rethinking markets, allotments and modes of procuring food that are relevant to urban procurement). The methodology of the project is to "compare by context" how these three levels materialize in the three cities: which social actors are actually engaged, through which concrete actions, and how politics and governance affect what is otherwise largely depicted as a mere issue of economics and/or sustainability (how to produce and procure food sustainably at affordable prices). This way, so-called (post)socialist food-ways assume a particular significance as not necessarily "the odd one out" in EU regions and economies, but rather as one of the possible identifiable cultural and economic pathways that collectivities take as they are informed by specific histories, territories, local economies, and social or demographic challenges. This article focuses on very different urban forms of food rescue and reallocation in Gdansk, namely through the grassroots activities of Food Not Bombs and through the Food Bank. Based on participant observation of relevant case studies in gentrifying Gdansk, the article focuses on the re-invention of "food waste", of food gifting, and food rescue.
\end{abstract}

KEYWORDS: Food gifting, Food Not Bombs, Food Bank, collective food procurement, solidarity

\section{RESEARCH FRAMEWORK}

The theoretical and methodological framework of this article is the on-going Food Citizens? project, which compares ethnographic cases of "collective food procurement" in three "post-industrial" cities of comparable size and population across the European

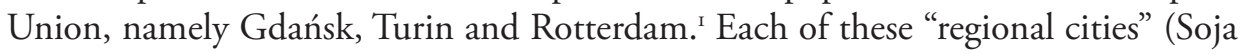

I For a definition of "collective food procurement", see Grasseni 20I8. The project "Food citizens? Collective Food Procurement in European Cities: Solidarity and Diversity, Skills and Scale" has received funding from the European Research Council (ERC) under the European Union's Horizon 2020 research and innovation programme (Grant agreement No. 724I5I, www.foodcitizens.eu). 
20IO) has distinctive national and local styles of collective food procurement, which exceed the conceptual and empirical framework of "alternative food networks" (Goodman, DuPuis and Goodman 20I2). The project asks how networks of social actors organize themselves at commensurable levels of intervention, one of which is "urban foraging", namely procuring food in the city (not necessarily by gathering and picking freshly grown food, but collecting it from available urban sites). In this article, we focus on two alternative manners of foraging for food without money in the city of Gdańsk, explaining how each method is embedded in radically diverging political imaginaries of food-gifting. Based on participant observation by Gracjasz, we compare and contrast the Food Bank of Tricity (a private-public partnership for food support to those in need) with the anarchist movement Food Not Bombs (FNB), which has been active for twenty years in the centre of Gdańsk. "The comparative method works best when the entities to be compared are different enough to present interesting contrasts, yet similar enough for the variations to be disciplined" (Jasanoff 2005, 29). In our case, both Food Not Bombs and the Food Bank practice food-gifting, but each represents idiosyncratic ways of doing so which reveal the often tacit but unique circumstances that define them as an "alternative" form of food procurement to buying food in the city.

Poland enjoys a continuity of informal food supply chains, while also projecting itself as the new granary of Europe. For example, at the 20I5 Universal Exhibition Feeding the Planet. Energy for Life in Milan, Poland boasted the largest and most visited pavilion of all Eastern European states represented, competing for popularity with the Italian host itself. Shaped in the form of a giant stack of apple crates, it displayed a cunning compromise between economic prowess and traditional sensibility. As the largest EU grain and apple producer, the Polish pavilion showcased its technological advancement with numerous multimedia displays, while also offering an interactive human-sized digital "genius" that would answer the public's questions on Polish agricultural traditions, and advertised traditional Polish cuisine and local products. Despite, as in other post-socialist countries, everyday social discourse still including some of the stigma of a "perpetual state of becoming European" (Bodnar 2008, I4I), Poland is economically well integrated into the capitalist "West". It is therefore all the more interesting to investigate how models launched in America, where excessive and intensive food production coexists with diffused citizen starvation (Patel 20I2; Jacobson and Silverbush 2013), namely food banks and Food Not Bombs, take root in Gdańsk, given the diversity of their respective social values and premises.

Critical food studies research has generated a sizable literature on food tastes and changing patterns of food consumption in Poland. For example, Aleksandra Bilewicz and Ruta Śpiewak (2018) note that so-called alternative food networks (AFN) in Poland tend to be based on individualistic motivations, and favour taste and the organoleptic qualities of food. These networks can be characterised by a "distrust 
toward the norms and regulations imposed from above" (2018, 20), which translates into a distrust towards ecological labels. In this reading, AFNs in Poland are driven first and foremost by personal benefits, rather than ecological motivations (Bilewicz and Śpiewak 2018, 19; 2015). Some AFNs, therefore, attract only the upper middle-classes, making access to "good, healthy and quality food" a matter of socio-economic exclusivity (Bilewicz and Śpiewak 2015). Moreover, the high prices of ecological products at specialised open-air markets effectively exclude people from lower income groups (Kopczyńska 2015).

Taking the socialist heritage into account, Harper claims that "the ability to support oneself through small-scale business endeavours was read as an economic rebellion against centralized, corporate state hegemony" (1999, 97). The Polish economist and economic historian Jacek Kochanowicz suggests that face-to-face relations are more trustworthy than those "within and between large and formalized systems" (Kochanowicz 2004, 67). This suggests that the continued existence of an informal food procurement system would be important to contemporary socio-economic processes. It also indicates that the emergence of diverse types of alternative provisioning is neither necessarily a result of, nor reflective of, western models or influence. Polish food cooperatives and open-air markets are culturally and historically rooted in pre-socialist times - the idea of cooperativism developed in Poland by Edward Abramowski was inspired by the French economist and historian of economic thought, Charles Gide but equally are re-shaped by both socialist and post-socialist processes. In Poland, in contrast to other then-members of the Soviet Bloc, most farmland did not undergo collectivisation, instead remaining in the ownership of families; this strengthened the already existing network of informal economies, because families could trade home-produced food outside the purview of state authorities (Haukanes and Pine 2004, I08).

Diana Mincyte (20II, 43) argues that food procurement is a performative practice, "domesticating" food into daily routines. However, as Hébert and Mincyte (20I4, 209) underline, narratives and practices of self-reliance in food procurement may "further entrench capitalist logics": for example, Lithuanian networks of the informal production and exchange of raw milk reposition "consumption as set in broader infrastructures, subjectivities, cultural formations, and power relations" (Mincyte 20II, 43) - in other words, as the co-editors of this special issue suggest, they situate food procurement in a "cultural politics" which reproduces "social order in performing daily tasks and routines". This reveals how food procurement is not a neutral practice, but rather (re)shapes personhood (see Dunn 2004) in ways that are germane to specific cultural and historical circumstances.

Nowadays, food self-provisioning is still widespread in Poland and it is believed to "result in beneficial environmental or social outcomes", which "do not relate directly or indirectly to market transactions" and "are not represented by the practitioners as relating directly to environmental or sustainability goals" (Smith and Jehlička 20I3, 
I55). Such practices and networks - (as well as self-managed allotment gardens during the socialist era, see Smith and Jehlička 2007) are by nature informal and rely on "economies of acquaintances" (Kopczyńska 20I7). In such networks, maintaining informal, often kin-based relations is of key importance for mutually successful transactions, while the working of food cooperatives is based on shared "objectives, ideologies, lifestyles, statuses, and positions” (Kopczyńska 20I7, 653). A contrast between informality and formalization will inform some of our analysis of food gifting in a grassroots vis-à-vis that of a formalized setting (namely the circle of Food Not Bombs activists and the patrons of the Food Bank system in Tricity).

Here, we find that a distinction should be made between activists, such as those active in food sovereignty networks, and discerning consumers. Gracjasz's broader fieldwork observations in Gdańsk confirm that organic food markets, vegan shops and food cooperatives may well serve more mainstream motivations, such as individual satisfaction, health concerns and a sense of distinction based on taste. When we investigate "collective food procurement networks", however, more often than not we find engaged circles of activists working to challenge the dominant food system characterized by large organized distribution (supermarket) chains. They may challenge the power of such systems by promoting veganism, or advocating using animals in farming for their positive influence on soil and thus crops, or supporting small and local farms to shorten the food chain. Such efforts may be mainly for environmental, but also for labour rights' reasons, for example when activists promote boycotting farmer exploitation.

Through the following juxtaposition of two in-depth ethnographic case studies, we show how collective food procurement networks articulate multiple discourses and practices of solidarity - specifically food-gifting in the city. We will analyze in particular the ways in which food-gifting is practiced, the ways in which it is appreciated by beneficiaries, and how volunteers or employees are engaged in it in both cases, in order to draw some conclusions and syntheses on the values that are upheld and the performative practices that frame food gifting in either case. In so doing, we critically assess their potential meanings in terms of a "cultural politics of food".

\section{METHODOLOGY}

The ethnographic fieldwork upon which we base our analysis was carried out by Gracjasz in Gdańsk within the methodological framework of the Food Citizens? project. ${ }^{2}$ This is premised on the lesson of Michael Herzfeld's "polyglot perspectives"

2 Please see the publicly available resources of the project methodology, including a shared Protocol for Ethnographic and AudioVisual Research in each of the three main sites of fieldwork: https:// www.universiteitleiden.nl/en/foodcitizens/dissemination/public-resources (accessed 07.I0.2020). 
(2009), according to which fieldwork benefits from linguistic proficiency and fieldwork in one's own language cannot per se be defined as "auto-ethnography". Being Polish by birth and yet having lived outside of Poland for about ten years positions Gracjasz as an ethnographer in Gdańsk. A native Polish speaker, she is familiar with the basic cultural codes and common socialites that Herzfeld calls "cultural intimacy" (Herzfeld 1997). On the other hand, living abroad and using English as an academic and everyday language allows her to balance a thin insider-outsider line. Being Polish yet somehow foreign, her ethnographic attention can hone in on the idiosyncrasies of everyday "banalities".

The fieldwork upon which this article is based sums up nearly 1.5 years of living in Gdańsk (from January 2019 to July 2020, interspersed with sporadic project meetings in the Netherlands). As Gracjasz comes from the south of Poland, Gdańsk is perhaps one of the furthest places from "home" in the country. In order to begin fieldwork, she got to know the city's history and took actions to integrate herself into its social life. She visited local historical museums, cultural institutions (e.g. the World War II Museum, the European Solidarity Centre) and several libraries, and met and spoke with local scholars - sociologists, anthropologists, historians, humanists, architects and urban planners. Her fieldwork is not an auto-ethnography as she was not living the life she would live normally, but rather she moved to Gdańsk from the Netherlands where she had lived for around four years. At the same time, her research can be considered auto-ethnographic if we understand it as a way of producing holistic research, informed by personal experiences and aimed at articulating issues that elude everyday attention (Ellis and Bochner 2000).

The structured data collection methods included 65 interviews, mostly audio-recorded (some video-recorded), completed by four focus groups and nine "cultural maps" drawn with research participants. However, as the main research method Gracjasz used ethnography, namely participant observation, which combines taking notes of cultural happenings and engaging with these (Geertz 1973; Goodall 200I). The longitudinal dimension of the fieldwork allowed her to become part of several networks - specifically Food Not Bombs in Gdańsk - participating in their weekly actions, while at the same time observing their inner struggles, successes and developments. At the same time, Gracjasz volunteered in one of the three social shops of the Food Bank of Tricity, based in Nowy Port. In both cases, participant observation enabled gathering documentary evidence (with consent where needed) such as online articles, website screenshots and copies of archived documents. The fieldwork also resulted in a voluminous audio-visual archive of around four thousand photographs and more than 300 gigabytes of videos. In order to select participants, snowball sampling was used. This is a commonly accepted qualitative research method that allows access to a group by starting with one contact who then leads to others. The ensuing serendipity is considered as one "of the key characteristics of the ethnographic method" (Rivoal and Salazar 2013). Gracjasz also contacted people via social media (mainly 
Facebook) or by calling contact persons whose phone numbers could be found on publicly consultable websites. The following ethnographic vignettes introduce the relevant case studies. Their aim is to explain the actions of participants, describe the atmosphere of the events and bring the reader closer to the scene in the first person singular, following the anthropological method of extracting larger inferences from in-depth insights.

\title{
ETHNOGRAPHIC CASE STUDY: FOOD NOT BOMBS
}

\begin{abstract}
We are standing in the middle of the main square in Gdańsk's Old Town, surrounded by colourful tall buildings that remind one of Danish or Dutch medieval towns. Behind us there is the historic $17^{\text {th }}$ century Fountain of Neptune. Apart from being a tourist attraction, it is also one of the main meeting places for strikes and demonstrations. As it is Sunday, there is a bustling crowd of tourists, both foreigners and Polish. We have set up our plastic table and hung the banner "free hot meatless meals" written in four languages (Spanish, Russian, Polish and English). A huge pot of soup is placed on the floor, while several loaves of bread gifted by a local bakery are placed on the table. When the city bells ring midday, we see our first beneficiaries coming from a distance. They are easily discernible from the classy tourists, as they wear randomly arranged layers of clothing, often stained and dirty. We have met most of them already because they come every week. Some of them have visited regularly over the last few years. Sometimes they stop coming, never to be seen again, and we wonder if they have moved on, found a way to make ends meet or passed away. The steaming soup, very similar to the one from last week, is being served in plastic bowls by one of the volunteers of Food Not Bombs. ${ }^{3}$
\end{abstract}

Food Not Bombs is a movement born in the United States in around 1980 as part of the anti-nuclear movement, setting itself against "the perverse priorities of the US state and capital" spending money on nuclear weapons rather than on hungry citizens (Heynen 20IO, I229). The movement indicted the "link between the waste of nuclear power and arms production and there invigoration of inequality and poverty in the US" (Heynen 2010, I229), and since then it has inspired over 400 self-organized movements worldwide. Food Not Bombs Gdańsk has existed since 20or (Food Not Bombs 2019). Every year, from November through to March, its volunteers pick up excess vegetables from a local food market. Then, on Saturday night, they cook a pot of vegan soup together and collectively distribute it on Sundays.

The Excel sheet scheduling the division of labour established at the start of the season is empty, but still the soup gets cooked every week - not without hassle. Every week, someone picks up the vegetables from the market, usually someone with a car

3 This ethnographic vignette is based on a series of observations gathered during Gracjasz's weekly attendance of food distribution actions with FNB in Gdańsk during two separate seasons: from January 2019 to March 2019 and from November 2019 to March 2020. 
because of the large amounts of vegetables. Then the collected food has to be transported to a place for cooking. Often, the location is unknown until the day before. At times, it is really hard to find a place, and when it is far away or difficult to access by public transport, not many members of the group show up. Often, different people do the cooking and the transporting. Once the pot of soup is placed in someone's car, it is taken to the centre of Gdańsk. Here one can meet other members of FNB, those who could not pick up the vegetables or cook, but who come to the serving location to show support, pour soup into plastic bowls and hand out pieces of bread. Despite the seemingly scattered and inefficient organization of the process, over the years people have developed ways to participate in the tasks that suit them. Perhaps the best proof that this spontaneous self-organization functions is the fact that soup is successfully distributed every Sunday of the winter season, without fail. After all the food is gone, we clean, pack up and discuss about whose house we will meet to cook at next Saturday.

Food Not Bombs' mission, in principle, is to target those most in need. However, as the Old Town has become increasingly touristic, the soup is given to anyone who wants it, including passers-by. Inspired by anarchist ideals, distributing free food without expecting anything in return, the group exposes the problem of poverty and challenges the dominant market-transaction ideology. This consciously marginal practice is a publicly and collectively performative call to a more sustainable management of resources, performed by a grassroots and unpaid group. De Musso (2010) has found similarly oriented practices among self-organised students gleaning at food markets in Bologna. As Heynen has observed, "unlike much charity, FNB works hard not to be complicit in the perpetuation of the capitalist states' biopolitics, but seeks to radically transform it" (2010, I233). This meme, published on the Facebook page of FNB Gdańsk, expresses the same message.

Milton Friedman was one of the most famous American free-market economists of the $20^{\text {th }}$ century. The Polish politician Ryszard Petru, inspired by Friedman, during his election campaign in 2017 for the party Nowoczesna (Modern), referred to Friedman's book There's No Such Thing as a Free Lunch (1975), using the same sentence as a slogan in Polish to critique the welfare system. The FNB Gdańsk meme (Fig. I) shows a black and white picture of Milton Friedman lost in thought, next to the Food Not Bombs logo with a fist holding a carrot, and the sentence: "There is no one like Milton Friedman anymore, but there are free meals". This irreverent sentence pointed to the fact that, actually, the meals being distributed by FNB are free, while also pointing out that Milton Friedman is now dead. This slogan generated a heated discussion on social media. One critique was that even though the food used by FNB is procured without money, it still had to be paid for by someone in the first instance: it had been bought by wholesalers and market vendors. They thus bear the costs of the "free meal". FNB responded that "free" might mean both "without costs" and 


\section{Nie ma już kogoś takiego, jak Milton Friedman.}

\section{Są za to darmowe obiady.}

FOOD NOT BOMBS GDAŃSK

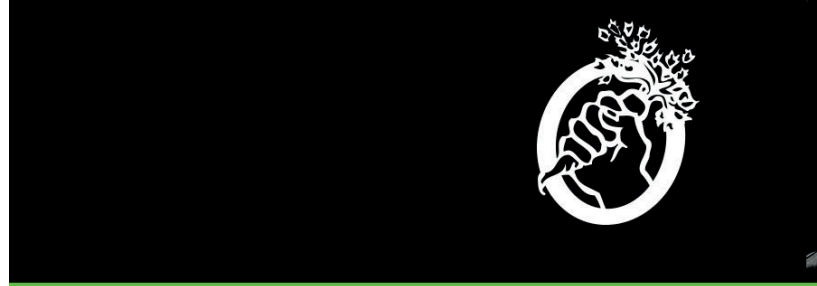

ROZDAJEMY BEZPŁATNE POSIŁKI WEGETARIAŃSKIE w NIEDZIELE 0 godz. 12.00 DŁUGI TARG pod NEPTUNEM

Fig. I. A meme referring to Milton Friedman's statement that "There is no such thing as a free lunch", was posted on the Facebook page of FNB Gdańsk.

"without paying", making clear that its members are aware that everything they do comes at a cost. However, by doing everything voluntarily and for free, and by not expecting anything in exchange for their work, the members of FNB are challenging its monetary cost, and are making the point that the "free lunch" they are cooking is a deliberate act of opposition to neoliberal notions that nothing comes for "free". FNB's approach is thus political. Additionally, it engages in the action of feeding the poor and exposing the problem of homelessness, while simultaneously dealing - conceptually and politically - with the problem of food "waste" in capitalist societies.

FNB in Gdańsk is composed of around ten core members, people who have been actively engaged in the group for a few years. The group is entirely informal. The members taking part in its activities compose a tight social network. They also keep connected and active through leisure and political activities beyond those related to food procurement. Although the group is open, the members are also comfortable in its stable setting. They do not actively look for new members, but rather wait for people to find out about them and join. The group is united mainly by the members' shared ideology. The majority of them adhere to anarchist ideals and many come from 
the punk scene, which in Poland has its roots in the alternative scene of the 1990s. By providing "free lunches", FNB challenges capitalist norms of distribution and consumption, but also the conventions around the production of food, as preparing the food always happens in a group and in a private household with no health and safety oversight.

In the busy square, many pass us by. We recognize our usual beneficiaries, as they rush through the crowds towards our stand, forming a small queue. We always split tasks on the spot. Whoever feels like it, stands by the large pot and pours the soup into plastic bowls. Someone else passes out the spoons, another shares the bread, some people come to chat and give support. A few minutes after midday, other people join us: a young woman always bakes a cake and waits on the side until people finish eating from the trays; a Hare Krishna follower in his 50 s brings about 50 samosas (Indian deep-fried dumplings) as a Prasadam (a religious offering). Our stall consists of a small folding table, the pot and another smaller thermos pot, which keeps part of the soup hot and serves as an extra table. Behind us, on the metal fence surrounding the Neptune fountain, we hang the Food Not Bombs banner. Every now and then an intrigued tourist comes closer and asks about the price. Usually at this moment we point to the donation box (an old tin covered in anarchist stickers - fig.2) and explain that it is free food, but donations are welcome. On a good day, with many tourists and a particularly keen person holding the donation box, we can gather more than enough money to cover the costs of the dry products, the cooking oil and plastic bowls - all the products that cannot be obtained for free at the market. ${ }^{4}$

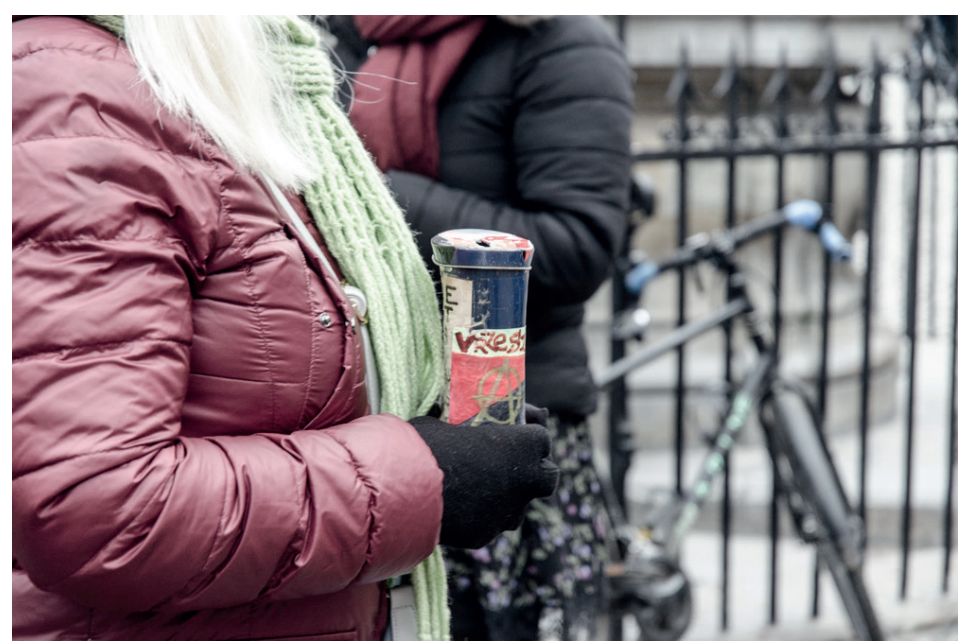

Fig. 2. A member of FNB holding a donation box. Photo Aleksandra Gracjasz

4 This ethnographic vignette is based on a series of observations gathered during Gracjasz's weekly attendance of food distribution action with the FNB in Gdańsk from January 2019 to March 2019 and from November 2019 to March 2020. 
In a Maussian way, the tourists often feel obliged to give a small donation, especially when they realize that the food is primarily intended for the poor and the homeless. They feel morally obliged to support the cause and the poor, mainly because they can be seen close up. In this way, the tourist becomes the main source of income for FNB. In earlier days (2000-20I0), FNB organized crowdfunding during concerts at friendly clubs. Before that, the members covered the costs themselves.

Food waste is regarded by Food Not Bombs' activists as an excess of the capitalist system. To align our interpretation of "excess" to theirs, we tap into the influential concept of "dépense" coined by George Bataille (1985), a significant representative of the surrealist movement of early $2 \mathrm{O}^{\text {th }}$ century France and a lingering, though often unrecognized, source of inspiration for the anarchist movement. Excess restores something to its true being outside of its being flattened into a commodity. According to Bataille (1991), the excess found in the natural world is necessary for growth: for example, the sun "gives without ever receiving" (Bataille I991 28). Excess can be achieved through sacrificial acts, but also through being "luxurious".

Food Not Bombs use the excess of the capitalist system: they receive produce enriched by the energy of production, transportation and sale of other food at the market, they add the extra energy of their own work by picking up, cooking and distributing it, and by doing so they transform leftovers previously deemed to be without value into "worthy" meals. They are handling waste (literally, with their own hands, and figuratively, saving it from being wasted), reinventing it into wholesome hot meals. Their actions salvage the energy other people already put into growing and transporting produce which would otherwise be thrown away. However, they give it away, asking for nothing in return. This is a symbolic act that puts new "added value" into an otherwise leftover commodity. They make it valuable again, but without re-commodification: they give it away.

\section{ETHNOGRAPHIC CASE STUDY: THE FOOD BANK}

It is Wednesday morning as I cycle to Nowy Port to volunteer in the Social Shop of the Food Bank. The shop is located on a main street in an old bakery, in front of a primary school. A few steps lead up to the small porch and an entrance. Later in the day, the porch crowds with people waiting to enter. It is early, and we are waiting for a delivery. A white mini-bus with the Food Bank and Carrefour Foundation logos parks on the side street and a few men in their 50 and 6os bring boxes of food inside. The driver is a Food Bank employee, the other men live in the homeless shelter and were asked to help out in exchange for free food. The boxes contain food with close-to-expiry dates and were collected from several supermarkets in the area. There are plenty of ready-to-eat products and, as always, the content of the boxes is random, unpredictable 
and often unfamiliar to the average customer (e.g. kebab sandwiches, avocado smoothies, Chinese sweet rice balls, or vegan spreads, for example).

At Ioam, we open the door and welcome the first "customers". Although the Social Shop does not sell, people pay for the products with points allocated by the Miejski Ośrodek Pomocy Społecznej (MOPS, the Municipal Social Welfare Centre). This points system was introduced as an element of economic education and a promotion of healthy eating habits: fruit and vegetables are cheaper, while meat and sweets the most expensive. Apart from the allocated points, choice is limited by the amount of food one is allowed to take. During the first few hours, the shop is open only to those that have received a "referral" from the MOPS. It is only during the last hour that the shop opens up to everyone. They are welcomed as long as they are sober, can provide identification and sign a form. If they follow these rules, anyone can collect up to I $\mathrm{kg}$ of free food three times a year. At the end of the day, we are left with several kilograms of food (at times close to 9okg) with today's expiry date. At this point, representatives from NGOs and charitable foundations pick up the food that has "become waste" for a second time.

The Food Bank in Trójmiasto (Tricity) is the local unit of a countrywide NGO, itself part of a global network of food banks. Its activities include making and distributing emergency food packages, holding cooking workshops and lectures on food waste, and maintaining the Social Shop that has been running in Nowy Port since February 20I9. This project won a contest organized by Miejski Ośrodek Pomocy Rodzinie (MOPR, Municipal Welfare Family Centre) - it was the only participant. MOPR is a public institution funded by The City of Gdańsk, including funding specifically designated for the Social Shop. In return for its financial support, MOPR has the right to control the Social Shop and it requires detailed reports with attached invoices. This generates a great deal of paperwork that must be meticulously completed - lest funding be lost. Access to public money triggers a host of expectations and lays the groundwork for making the Food Bank responsible for handling the problem of poverty and food waste on behalf of the local government.

Picking up the food products, placing them on shelves and in refrigerators, and re-distributing them among the customers are labour-intensive activities done by the poorly paid workers of the Food Bank. In fact, some of these workers admit that this job is more of a hobby, which they can afford thanks to other reliable sources of income. In practice, the government subsidizes an organisation that relies on exploiting semi-voluntary labour, devolving responsibilities for the poor to a community organisation. However, the government nonetheless maintains great decision-making powers over the Food Bank's daily processes. Those closest to the needs of the poor cannot use

5 This ethnographic vignette is based on a series of observations gathered during Gracjasz's weekly voluntary work at the Social Shop of the Food Bank in February and March 2019 and again from July 2019 to July 2020. 
their knowledge to make informed decisions about who needs what. The workers of the Social Shop have direct contact with its customers, and thus know how much or how little food is delivered and re-distributed. However, they are not authorised to change the allocation rules, such as the number of people who can receive "referrals" to be Food Bank beneficiaries or the amount of food allocated to each person, without prior communication with the MOPR.

Not only does the Food Bank take on the government's responsibility of feeding the poor, the Food Bank rescues food "waste" and creates an institutionalised system for its distribution. Indeed, it serves as an intermediary between the state and the food industry (Butcher et al. 20I4). The "problem of food waste" that the supermarkets would otherwise have to deal with, including its monetary consequences, disposal costs and taxes, is dumped (pun-intended) on the Food Bank. Supermarket profits, however, are not generally accounted for by those analysing the role of food banks in society. Garrone, Melacini and Perego (20I4) highlight how supermarkets systematically rely upon donations to food banks in their waste management practices. In this sense, food banks may be characterized as a mechanism that distracts from the actual structural problems of food poverty (Booth and Whelan 20I4). As early as 1998, the American sociologist Janet Poppendieck articulated a critique of the food bank system as perpetuating hunger and inequity. In Sweet Charity?: Emergency Food and the End of Entitlement, she exposes this as part of a wider range of flawed aspects of charitable food giving and food assistance policies in America. As Tarra Keny and Colin Sage underline in their study of food banks in the United States, the fundamental "structural unsustainability of the food system remains unchallenged" (2019, 28I).

The Food Bank, in a sense, performs the role of the state in assisting the poor. The Food Bank has undertaken a job that has traditionally belonged to the state: caring for economically at-risk groups. However, it also executes multifaceted actions, which include not only food re-distribution (which can equally be characterised as waste management or the management of food excess) but also the education of the poor, for example through cooking workshops. A food bank does not instil co-operation and mutual exchange (which Kropotkin (1995) says could form the basis of a functional political economy). Charitable gifting, to both handle excess food and help the poor, does not contribute to implementing the right to (good) food for everyone. Rather, the people who are beneficiaries of the Social Shop are made to choose from processed products and occasionally from fruit and vegetables that are no longer fresh. In fact, the food they can choose from is often cheap and unhealthy, as evidenced by the fact that among several corporate partners of the Food Bank is the American fast food company KFC. It is perhaps to counter this effect that the Social Shop has, at the behest of the government, introduced a points system which not only simulates market transactions, but is a way to cajole "consumers" to choose fruit and vegetables by 
making them the cheapest choices for the beneficiaries, and at the same time to discourage them from eating sweets, by making them point-expensive.

In 2018, 590 people received food through the Social Shop in Gdańsk (Związek Stowarzyszeń - Bank Żywności w Trójmieście 2018). The fact that food categorised as "waste" is given to the underprivileged places them in the "lowest" category - people who have to eat "waste" because they have neither the means nor the agency to procure fresh products. This association is apparent to the beneficiaries, who often feel shame when they come for food (cf. Horst, Pascucci and Bol 20I4). Additionally, being a beneficiary of the Food Bank requires time. This is especially so if one is not considered the most in need and therefore is not gifted the special "referral" granting access to the shop during its opening hours. Without such a voucher, one must wait in a queue, as a limited number of people are allowed to enter at any one time. Ironically, people in this situation explain that such time requirements in fact take away from the time one could use to search for a job.

\section{SYNTHESIS AND CONCLUSION}

The foodscape in Gdańsk is not entirely readable through the lens of individuals "neutrally" shopping and exercising their "consumer choice". In the cases we have described, eaters do not buy, but are gifted their food. The food comes to the Food Bank or to the Food Not Bombs' soup cauldron through a chain of actions. FNB activists "glean" fruit and vegetables from fresh-food urban markets. They gather, sort and transport them to a place for processing and cooking, before delivering hot meals to the serving location. Here they gift cooked food to all passers-by, whether tourists or the local homeless. In contrast, the Food Bank gathers food from corporate donors and is sponsored by both the city government and supermarket chains. It depends on the work of both salaried and volunteer "shopkeepers", and "sells" the donated food to accredited beneficiaries (the homeless and economically disadvantaged individuals) through a points system that is meant to educate them in how to shop responsibly. This system produces waste in its turn, namely undistributed food which is then passed to organised charities according to procedures that are regulated by law.

These formal and informal activities, driven respectively by anarcho-syndicalist ideologies and by government regulations, organise the gifting of food in radically different ways. Each premises a set of assumptions (about who should receive gifts, what is excess food and how it should be dealt with) which extend to what is citizenship, solidarity and charity, how market and society should interact, as well as to expectations of and from the beneficiaries. Before concluding, we turn our attention below to the re-framing of "food waste" in gentrifying Gdańsk through a final ethnographic cameo. 
The visits of FNB activists to the market are expected by vendors. In fact, there is a sense of familiarity between some of them and Food Not Bombs' members, built on relationships cultivated over the last eight years. At the end of October, some vendors are already waiting for FNB, and express their annoyance when they come a week later than the year before, as there is already so much food leftover that could have been used for cooking. Some of the vendors applaud this initiative openly: as helping the poor, giving their own time and energy, and not wanting anything in return. What strengthens the relationship with the vendors is the repeated FNB "gratitude ritual", namely sharing a warm meal cooked from vegetables from the market with all the vendors at the end of the season. ${ }^{6}$

We can compare the nuanced types of solidarity that are engendered through and around these different practices of food gifting. For Food Not Bombs, solidarity is not only performed between cookers and eaters, but also between collectors and vendors at the market. The latter come to know the food activists over time, empathize with the beneficiaries (even though at a distance) and show their support for the activists' initiative by offering unsold fruit and vegetables in edible conditions. In some cases, they set aside the produce to be collected so that it is not sold or spoilt by sitting with rotting food. Technically, they are not giving away "waste", but are rather making a conscious donation. In return, FNB activists "bring back" the cooked leftovers and offer the vendors hot soup. Once again, they gift it to everyone, both the vendors who gifted fruit and vegetables, and those who did not. Additionally, they feed the elderly people who come for their weekly shopping to the market and stay to share the meal.

In contrast, the "charitable giving" of the corporate donors supplying the Food Bank can be considered to also be compelled by provisions concerning food expiry dates, and no effort is made to set aside, sort or inject new value into this food procurement system. Value addition is instead managed by the city administration, which organises the Food Bank volunteers and pays its employees.

Unlike the points system of the Food Bank, which recreates a market transaction in the act of gifting, Food Not Bombs unmakes market transactions. Wasted food is given anew "use value", but without a new "exchange value", as it can neither be sold nor bartered. Instead, it is given away. Even though the labour needed to prepare the final product could be used to determine the exchange-value of the gifted food, for example by translating a certain amount of hours or the cost of petrol into a "value", this is consciously avoided. If price is understood in terms of its Latin root pretium, meaning "reward, prize, value, worth", then the reward for all the time, work and

6 Due to the COVID-I9 pandemic, in the spring of 2020 FNB activists for the first time could not share the meal with the vendors of this market. This ethnographic vignette is based on observations gathered by Gracjasz while attending food collection at the Gdańsk market Zielony Rynek in winter $2019 / 2020$. 
energy invested in the process of soup-making is immaterial and intangible. This is not a "price" as commonly understood, but rather a sense of fulfilment, a good deed and a political statement. Moreover, through this process FNB activists create and maintain a close network of relations. They know the vendors and beneficiaries - and they redistribute food across this network in an egalitarian way as intermediaries. Even though not everyone is equally positioned in it, this system emphasises the incommensurable value of social relations, one made invisible in capitalist exchange. Indeed, the fetishization of the commodity described by Marx (1990) whereby, in the context of market exchanges, the value of a commodity is extracted and translated into independently circulating money is challenged by the actions of FNB: members do not calculate a monetary value for their work. Rather, the value of their actions is understood in incommensurable terms, as they create relationships and solidarity networks with the vendors and the beneficiaries, which they neither attempt to translate into a price, nor into any form of "exchange", as purposefully indicated by the fact that everyone receives food on an equal basis: tourists and the homeless, vendors who have donated and those who have not.

Their gifting actions also have the potential to reconceptualise and bring nuances to Marcel Mauss' theory of the gift, particularly that any "free" gift comes with unspoken expectations of reciprocity (1970, 50). Activists of Food Not Bombs emphatically express that they do not expect anything from the beneficiaries, not even their participation in preparing the meals. However, a tacit relationship is built through the act of commensality, of being together in a public space, of sharing a meal rather than giving it as charity without partaking oneself. In this case, and this case only, the giver actually shares the gift with the receiver. To an extent, expectations are somehow inbuilt, however ambivalently. There is a donation box, but it is often not even visible. When it is made visible for beneficiaries to "give back", it is only partially made visible: that is, activists make the donation box visible to tourists who entered into the network of redistribution as beneficiaries.

We have observed a nuanced "cultural politics" of food-gifting in action in the city of Gdańsk, by focusing on the re-invention of food waste through re-valuation and redistribution on the part of Food Not Bombs, and through charitable and educational food-gifting in the Food Bank. While both case studies share the idea of helping the poor by increasing their access to food, and managing what would otherwise become wasted food, they do so in different ways and by creating different, almost opposing types of solidarity. In one case, the redistribution occurs strictly in terms of egalitarian efforts that refuse any form of hierarchy and any form of accounting (even of a distinction between tourists and the homeless, or between vendors who gift and those who do not). In the second case, charity is disciplined with a points system that is supposed to "educate" the beneficiaries to shop like customers, and to 
use their (gifted) credit in a wise way, making rational choices on the basis of price and quality.

\section{REFERENCES}

Bataille, Georges. 1985. Visions of Excess. Selected Writings, 1927-1939. Edited and translated by Allan Stoekl. Minneapolis: University of Minnesota Press.

Bataille, Georges. 1991. The Accursed Share. An Essay on General Economy. New York: Zone Books.

Bilewicz, Aleksandra, and Ruta Śpiewak. 2015. "Enclaves of activism and taste: Consumer cooperatives in Poland as alternative food networks." SOCIO.HU, 3: $145-66$.

Bilewicz, Aleksandra, and Ruta Śpiewak. 2018. "Beyond the 'Northern' and 'Southern' divide: food and space in Polish consumer cooperatives." East European Politics and Societies and Cultures, 20(Iо): I-24.

Bodnar, Judith. 2008. "Becoming bourgeois. (Postsocialist) utopias of isolation and civilization." In Evil Paradises. Dreamworlds of Neoliberalism, edited by Davis, Mike, Monk and Daniel Bertrand, I40-I5I, New York: New Press.

Booth, Sue, and Jillian Whelan. 2014. "Hungry for change: the food banking industry in Australia." British Food Journal, II6(9): 1392-I404.

Butcher, Lucy Meredith, Chester, Miranda Rose, Aberle, Leisha Michelle, Bobongie, Vanessa Jo-Ann, Davies, Christina, Godrich, Stephanie Louise, Milligan, Rex Alan Keith, Tartaglia, Jennifer, Thorne, Louise Maree, Begley, Andrea. 20I4. "Foodbank of Western Australia’s Healthy Food For All." British Food Journal II6(9): I490-1505.

De Musso, Federico. 20I0. "Omeopatia del rifiuto." https://www.fondazionebassetti.org/it/focus /2010/o7/omeopatia_del_rifiuto.html (accessed 07.I0.2020).

Dunn, Elizabeth. 2004. Privatizing Poland: Baby Food, Big Business, and the Remaking of Labor. Ithaca, NY: Cornell University Press.

Ellis, Carolyn, and Arthur Bochner. 200o. "Autoethnography, personal narrative, reflexivity." In Handbook of Qualitative Research, edited by Norman K. Denzinand and Yvonna S. Lincoln, 733-768, Sage: Thousand Oaks.

Ellis, Carolyn, Tony E. Adams, Arthur Bochner. 2010. "Autoethnography: An Overview." Forum Qualitative Sozialforschung I2(I): Article Io.

"Food Not Bombs - Gdańsk. 2019. Podkreślamy oddolność inicjatywy, brak hierarchii i samoorganizację." Chaos w mojej gtowie 19: 18-23.

Friedman, Milton. 1975. There's No Such Thing as a Free Lunch. University of Michigan: Open Court.

Garrone, Paola, Marco Melacini, and Alessandro Perego. 20I4. "Surplus food recovery and donation in Italy: the upstream process." British Food Journal II6(9): I460-I477.

Geertz, Clifford. 1973. The Interpretation of Cultures. New York: Basic Books.

Goodall, Bud. 20or. Writing the New Ethnography. Walnut Creek: Altamira Press.

Goodman, David, DuPuis, Melanie, and Michael Goodman. 20I2. Alternative Food Networks: Knowledge, Practice, and Politics. New York: Routledge.

Grasseni, Cristina. 20I8. "Food citizenship? Collective food procurement in European cities." Europe Now, 20. https://www.europenowjournal.org/2018/o9/04/food-citizenship/ (accessed 07.I0.2020).

Harper, Krista. 1999. "Citizens or consumers? Environmentalism and the public sphere in postsocialist Hungary." Radical History Review 74: 96-III. 
Haukanes, Haldis, and Frances Pine. 2004. "Ritual and everyday consumption practices in the Czech and Polish countryside: conceiving modernity through changing food regimes." Anthropological Journal on European Cultures I2: 103-130.

Hébert, Karen, and Diana Mincyte. 20I4. "Self-Reliance beyond neoliberalism: rethinking autonomy at the edges of empire." Environment and Planning Development: Society and Space 32(2): 206-222.

Herzfeld, Michael. 1997. Cultural Intimacy: Social Poetics in the Nation-state. New York: Routledge.

Herzfeld, Michael. 2009. "Polyglot perspectives.” Anthropological Quarterly 82(I): 3II-330.

Heynen, Nik. 20I0. "Cooking up non-violent civil-disobedient direct action for the hungry: 'Food Not Bombs' and the resurgence of radical democracy in the US." Urban Studies 47(6): I225-I240.

Horst, Hilje, Stefano Pascucci, and Wilma Bol. 20I4. "The 'dark side' of Food Banks? Exploring emotional responses of Food Bank receivers in the Netherlands." British Food Journal II6(9): I506-1520.

Jacobson, Kristi, and Lori Silverbush. 2013. A Place at the Table. New York: Motto Pictures.

Jasanoff, Sheila. 2005. Designs on Nature. Science and Democracy in Europe and the United States. Princeton: Princeton University Press.

Kenny, Tara, and Colin Sage. 2019. "Food surplus as charitable provision. Obstacles to re-introducing food as commons." In Routledge Handbook of Food as a Commons, edited by Jose Luis Vivero-Pol, Tomaso Ferrando, Olivier De Schutter, Ugo Mattei, 28I-294, Routledge: New York.

Kochanowicz, Jacek. 2004. "Trust, confidence, and social capital in Poland: a historical perspective." In Trust and Democratic Transition in Post-communist Europe, edited by Ivana. Markova, 63-84, Oxford: Oxford University Press.

Kopczyńska, Ewa. 2015. „Co to jest jedzenie naturalne? Socjonatura na targowisku.” Studia Socjologiczne 4(219): I8I-203.

Kopczyńska, Ewa. 2017. "Economies of acquaintances. Social relations during shopping at food markets and in consumers' food cooperatives." East European Politics and Societies and Cultures 3I(3): $637-658$.

Kropotkin, Pierre. 1995. The Conquest of Bread and Other Writings. Cambridge: Cambridge University Press.

Marx, Karl. 1990. Capital: A Critique of Political Economy. Vol. I. Translated by Ben Fowkes. New York: Penguin.

Mincyte, Diana. 20II. "How milk does the world good: vernacular sustainability and alternative food systems in post-socialist Europe." Agriculture and Human Values, 29(I): 4I-52.

Patel, Raj. 20I2. Stuffed and Starved: The Hidden Battle for the World Food System. New York: Melville House.

Poppendieck, Janet. 1998. Sweet Charity?: Emergency Food and the End of Entitlement. London: Penguin Books.

Smith, Joe, and Petr Jehlička. 2007. "Stories around food, politics and change in Poland and the Czech Republic." Transactions of the Institute of British Geographers, 32(3): 395-4IO.

Smith, Joe, and Petr Jehlička. 2013. "Quiet sustainability: fertile lessons from Europe's productive gardeners." Journal of Rural Studies 32: 148-157.

Soja, Edward. W. 2010. Postmetropolis. Critical Studies of Cities and Regions. London: Blackwell Publishers.

Związek Stowarzyszeń - Bank Żywności w Trójmieście. 20I8. Sprawozdanie merytoryczne za rok 2018. http://bztrojmiasto.pl/wp-content/uploads/2019/o7/sprawozdanie_merytoryczne_20I8.pdf (accessed 07.I0.2020). 


\section{AUTHORS' CONTACT:}

Aleksandra Gracjasz

Leiden University

e-mail: a.z.gracjasz@fsw.leidenuniv.nl

ORCID: 0000-0003-3480-3226

Cristina Grasseni

Leiden University

e-mail: c.grasseni@fsw.leidenuniv.nl

ORCID: 0000-0002-4545-1978

(c) 9 